Institut za

javne financije
NEWSLETTER

POVREMENO GLASILO INSTITUTA ZA JAVNE FINANGIJE

\title{
Što će biti s hrvatskim državnim potporama nakon pristupanja Europskoj uniji?
}

MARINA KESNER-ŠKREB Institut za javne financije

\section{UVOD I SAŽETAK}

Budući da Hrvatska pristupa Europskoj uniji (EU) za manje od godinu dana, zanimljivo je analizirati što je dogovorila na području državnih potpora, odnosno kakve nas prilagodbe na tom području očekuju. Iz analize o kretanju potpora u državama EUI2 koje su pristupile EU-u 2004. odnosno 2007. mogu se izvući određene paralele i za Hrvatsku (Jović, 20I2), te se može zaključiti da nas na tom području očekuju brojne reforme. No, na to također upućuje i dugogodišnja stagnacija stanja državnih potpora u Hrvatskoj, tj. reforme su postale neodložne.

Glavni nalazi analize državnih potpora u Hrvatskoj su sljedeći:

- U Hrvatskoj na području državnih potpora u razdoblju 2002-Io. nije bilo značajnih pomaka: udio državnih potpora u BDP-u i dalje je jedan od najviših u Europi, a struktura potpora gotovo je zamrznuta u cijelom razdoblju s dominacijom sektorskih potpora, prvenstveno u brodogradnji i prometu, što je samo pokazatelj da nisu učinjene značajnije strukturne reforme gospodarstva.

- Ukupne državne potpore ${ }^{\mathrm{I}}$ u Hrvatskoj su u 20Io. nakon neravnomjerne dinamike tijekom 2002-IO., još uvijek 2,4 puta više od onih u EU27 (I,2\% naspram 0,5\% BDP- $a$ ).

- Od 2002. kontinuirano rastu potpore poljoprivredi i ribarstvu od I,7 na 4 milijarde kuna 20Io., a sektorske potpore dosežu maksimume u izbornim godinama.

- Apsolutni rekorder je brodogradnja u koju je od 2002-Io. uloženo I3 milijardi kuna potpora. Slijedi promet s Io,4 milijarde, od čega najviše odlazi na Hrvatske željeznice.

I Državne potpore bez poljoprivrede, ribarstva i prometa.
- Ugovorom o pristupanju Hrvatske EU-u (u daljnjem tekstu: Ugovor o pristupanju) na području državnih potpora dogovoreno je sljedeće:

- ako se brodogradilišta ne restrukturiraju i ne privatiziraju do ulaska u EU, tj. ako se ne zadovolje uvjeti dogovoreni Ugovorom o pristupanju, Europska komisija (EK) može naložiti Hrvatskoj osiguranje povrata svih potpora za sanaciju i restrukturiranje (uvećanih za složene kamate), odobrene nakon I. ožujka 2006.;

- ako Željezara Sisak ne vrati državne potpore u iznosu od Ig milijuna kuna, morat će vratiti sve potpore za sanaciju i restrukturiranje (sa složenim kamatama), odobrene nakon I. ožujka 2006.;

- sedam mjera predstavlja "postojeće potpore" koje EK nakon pristupanja može preispitati, ali ne i naložiti njihov povrat. Hrvatska je zatražila da još četiri mjere uđu na taj popis.

- Približavanje datuma ulaska u EU ubrzalo je restrukturiranje brodogradnje, industrije člika te željeznica jer EU posebnu pozornost obraća upravo reformi državnih potpora budućíh članica.

- Nakon pristupanja EU-u, državne potpore prelaze u nadležnost EK koja će odobravati i nadgledati potpore kako to čini i u svim drugim državama članicama. Državne će se potpore u Hrvatskoj i dalje moći odobravati po istim pravilima po kojima se već sad ravna Agencija za zaštitu tržišnog natjecanja. 


\section{VELIČINA I STRUKTURA POTPORA U HRVATSKOJ DO 2010.}

Državne potpore u Hrvatskoj još uvijek su znatno više nego u EU-u. ${ }^{2}$ Dok su 20Io. države članice EU27 izdvojile 0,5\% BDP-a za podupiranje svojih poduzetnika, Hrvatska je za istu namjenu izdvojila 2,4 puta više ili I,2\% BDP-a. ${ }^{3}$ Slika nije nimalo bolja ako se hrvatske potpore promatraju u odnosu na one dodijeljene u novim državama članicama, tj. EUi2: udio državnih potpora u BDP-u 20Io. još uvijek je dvostruko veći u Hrvatskoj nego u EUı2 (I,2\% naspram o,6\%). Među novim državama članicama postoje velike razlike: u Bugarskoj se izdvaja o,04\% BDP-a, u Češkoj, Poljskoj, Sloveniji i Malti izdvaja se više od o,5\%, a najviše u Mađarskoj - I,94\% BDP-a. Tako je Mađarska apsolutni rekorder u korištenju državnih potpora; izdvaja najviše od novih država članica, ali i od svih država članica EU27. Da je 20Io. bila članicom EU-a, Hrvatska bi bila bora. Iako je vremenski raspon prekratak, i uzorak od dvije izborne godine premalen za neke čvrste zaključke o utjecaju politike na gospodarska zbivanja, ipak je zanimljivo uočiti ovu koincidenciju. Nakon izbora i vrhunaca dosegnutih 2003. i 2007., udio ukupnih državnih potpora u BDP-u sljedeće dvije godine opada.

Iduća izborna godina bila je 20II. (još nije obuhvaćena $u$ službenim objavljenim podacima AZTN-a), pa će biti zanimljivo vidjeti hoće li kretanje potpora potvrditi gornje procjene, tj. hoće li one $u$ toj godini nastaviti rast započet 20IO. Nakon izborne 20II., kad će potpore u najboljem slučaju stagnirati, dolazi 2OI2., tj. posljednja godina pred ulazak u EU. Iz iskustva novih država članica koje su značajno povećale potpore $u$ godini pred pristupanje EU-u može se očekivati da će i u nas postojati pritisci za rastom potpora.

\section{Grafikon I.}

Udio državnih potpora u BDP-u 2оIо. и EU-и i Hrvatskoj* (u \%)

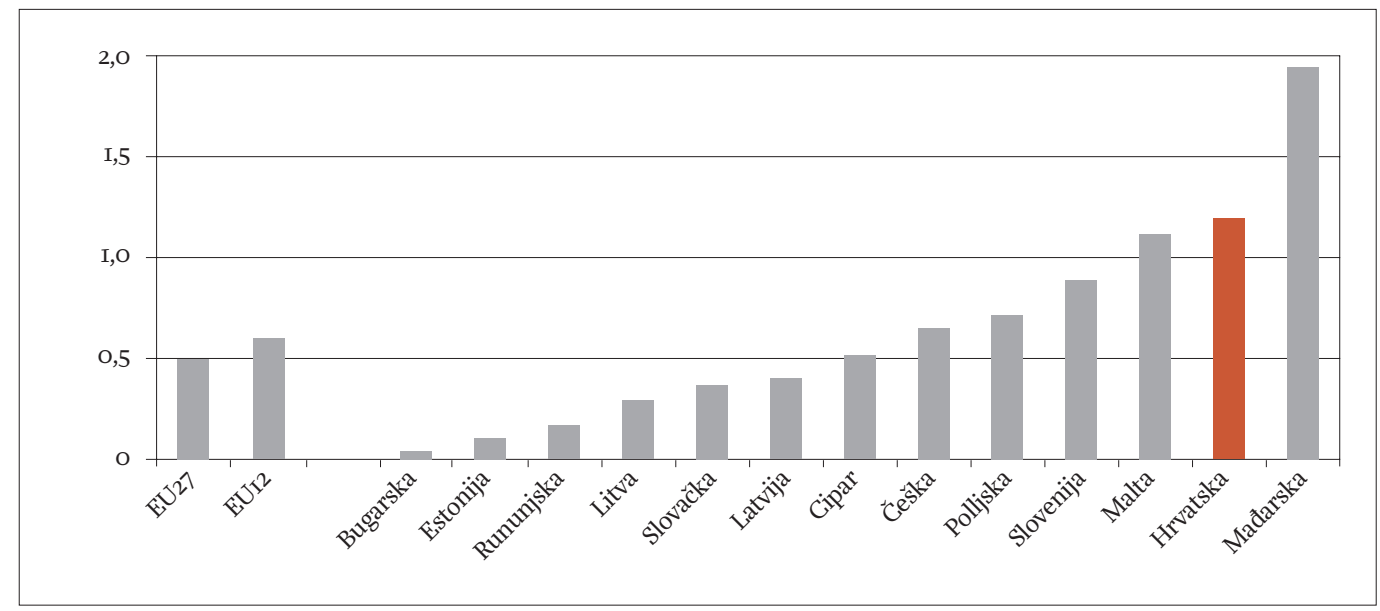

*Državne potpore bez poljoprivrede, ribarstva i prometa

Izvor: AZTN (2OII)

druga po veličini podupiranja poduzeća u čitavoj Uniji, odmah nakon Mađarske.

Put hrvatskih državnih potpora do ovako visokih udjela u BDP-u nije bio nimalo pravocrtan. Kada se promatra udio ukupnih potpora u BDP-u u razdoblju 2002-Io. (grafikon 2), lako se uočava neravnomjerna dinamika, tj. izmjenjivanje pada i rasta udjela. Zanimljivo je uočiti da je porast udjela potpora u BDP-u pratio politička zbivanja u zemlji, pa je dosezao maksimum 2003. i 2007. kada su krajem godine bili parlamentarni izbori i formirani novi sazivi Sa-

2 Analiza državnih potpora u Hrvatskoj temelji se na godišnjim izvješćima Agencije za zaštitu tržišnog natjecanja (AZTN) o državnim potporama.

3 Državne potpore bez poljoprivrede, ribarstva i prometa.
Kretanje udjela ukupnih državnih potpora u BDP-u pod presudnim je utjecajem kretanja sektorskih potpora. Gotovo identičan oblik krivulja ukupnih i sektorskih potpora tijekom cijelog promatranog razdoblja posve jasno ukazuje koliko snažno sektorske potpore određuju kretanje ukupnih potpora. To je i razumljivo ima li se u vidu da je u cijelom razdoblju 2002-Io. najveći udio u ukupnim potporama bio onaj sektorskih (tablica I).

Sljedeća specifičnost na koju valja ukazati jest kretanje potpora poljoprivredi i ribarstvu. Njihov udio u BDP-u ne prati kretanja sektorskih potpora, već potpore poljoprivredi kontinuirano rastu gotovo autonomno od drugih zbivanja u gospodarstvu, a udio u BDP-u im se nakon 2004. gotovo udvostručuje (o,7\% 2004. na 1,2\% 20IO.). 
Grafikon 2.

Kretanje udjela državnih potpora u BDP-и и Hrvatskoj, 2002-Iо. (и \%)

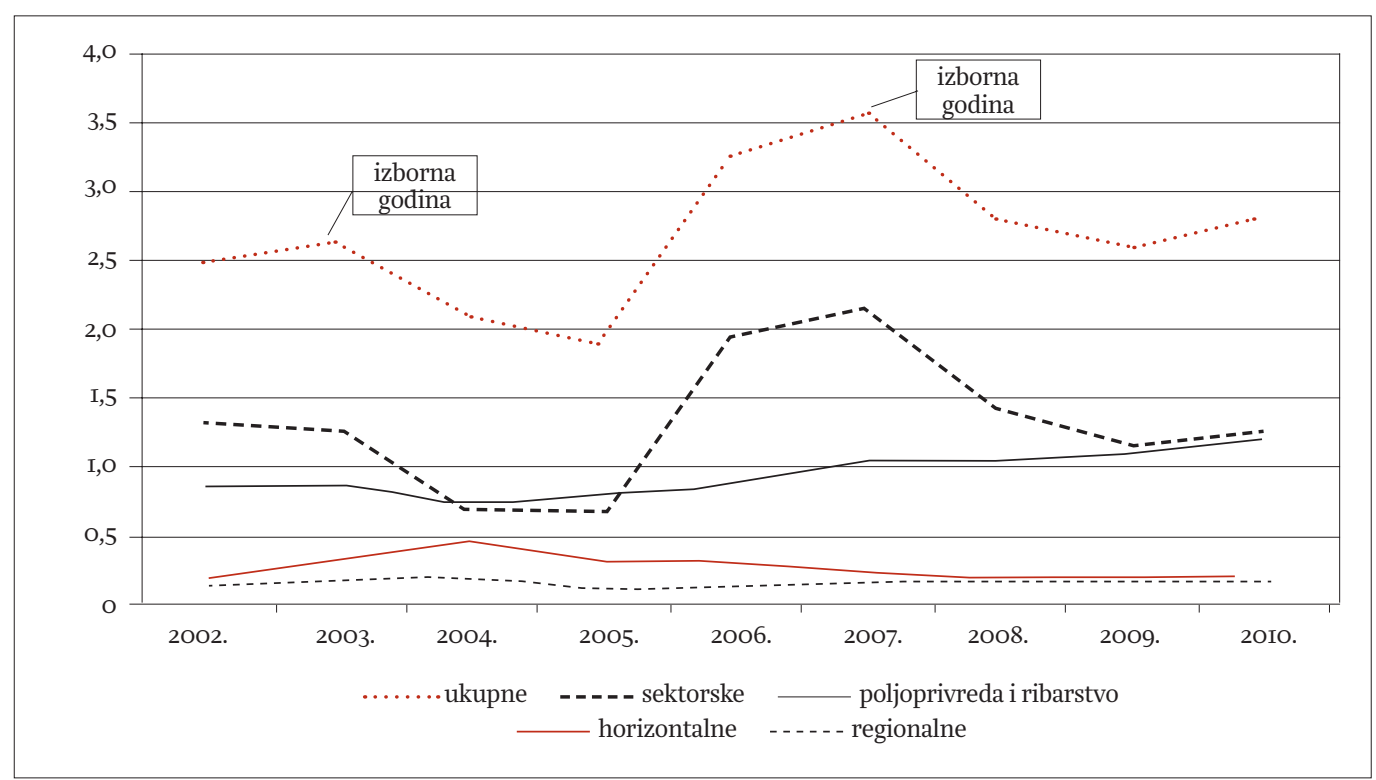

Izvor: AZTN (2OII)

Prema važećim propisima, AZTN ne nadzire, niti detaljno prati potpore poljoprivredi pa se u njihovim izvješćima nalaze samo podaci o ukupnim iznosima tih potpora, a ne i detaljnije informacije. Zato se, bez ulaženja u problematiku podupiranja poljoprivrede, ovdje samo ukazuje na stalni uzlazni trend.

Tablica I.

Državne potpore (bez poljoprivrede) prema kategorijama, u razdoblju 2002-Io.

\section{Kategorije potpora}

Horizontalne potpore

Zapošljavanje

Istraživanje i razvoj

Mali i srednji poduzetnici

Ostali ciljevi

Usavršavanje

Kultura

Zaštita okoliša i ušteda energije

Podupiranje pristupa financiranja u krizi

Sektorske potpore

Brodogradnja

Promet

Radiotelevizijsko emitiranje

Sanacija i restrukturiranje

Turizam

Ostali sektori

Financijske usluge

Proizvodnja čelika

Regionalne potpore

UKUPNO

\begin{tabular}{|c|c|c|}
\hline \multicolumn{2}{|l|}{ 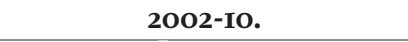 } & \\
\hline (mil. kuna) & $\begin{array}{c}\text { udio u } \\
\text { ukupnim } \\
\text { potporama }(\%)\end{array}$ & (mil. kuna) \\
\hline
\end{tabular}

6.733

2.207

I.097

I.O25

980

660

404

I86

171
34.286

I3.083

I0.434

5.356

2.361

I.479

917

$4 \mathrm{O} 2$

$25 \mathrm{I}$

4.014

45.034

$$
\text { potporama }(\%)
$$

$\frac{636}{93}$

2,4

2,3

2,2

I,5

0,9

0,4

0,4

$76, \mathrm{I}$

29,I

23,2

II,9

5,2

3,3

2, 3

0,9

0,6

8,9

IOO,O

\begin{tabular}{c} 
20Io. \\
$\begin{array}{c}\text { udio u } \\
\text { ukupnim } \\
\text { potporama (\%) }\end{array}$ \\
\hline
\end{tabular}

udio u ukupnim potporama bez prometa $(\%)$

\begin{tabular}{|c|c|}
\hline II, 8 & $\mathrm{I} 6,5$ \\
\hline $\mathrm{I}, 7$ & 2,4 \\
\hline $3, \mathrm{I}$ & 4,4 \\
\hline 3,2 & 4,4 \\
\hline $\mathrm{O}, \mathrm{O}$ & $\mathrm{O}, \mathrm{O}$ \\
\hline 0,9 & I,2 \\
\hline $\mathrm{I}, \mathrm{O}$ & $\mathrm{I}, 3$ \\
\hline 0,5 & 0,7 \\
\hline I,5 & 2,0 \\
\hline $77, \mathrm{I}$ & 68,I \\
\hline $23, \mathrm{I}$ & 32,3 \\
\hline 28,4 & $\mathrm{O}, \mathrm{O}$ \\
\hline 22,0 & 30,7 \\
\hline 0,5 & 0,7 \\
\hline 2,9 & 4,I \\
\hline 0,2 & 0,2 \\
\hline $\mathrm{O}, \mathrm{O}$ & $\mathrm{O}, \mathrm{O}$ \\
\hline $\mathrm{O}, \mathrm{O}$ & $\mathrm{O}, \mathrm{O}$ \\
\hline II,O & I5,4 \\
\hline $\mathrm{OO}, \mathrm{O}$ & IOO,O \\
\hline
\end{tabular}

n.p. - nema podatka

Izvor: AZTN (2OII) 
Nadalje, zabrinjavajuće je da se kontinuirano smanjuje udio horizontalnih potpora u BDP-u, tj. onih koje su namijenjene svim poduzetnicima, a ne samo izabranim sektorima i poduzećima. To su potpore namijenjene istraživanju i razvoju, malom i srednjem poduzetništvu, zaštiti okoliša, usavršavanju, zapošljavanju i sl. koje služe ispravljanju tržišnih neuspjeha i na taj način doprinose gospodarskom rastu, povećanju konkurentnosti i općem društvenom blagostanju. Nakon 2004., kada im je udio iznosio 0,5\% BDP-a, 20IO. se prepolovio pa iznosi samo o,2\%.

U koje je namjene u promatranom razdoblju od devet godina otišlo najviše javnog novca? U cijelom razdoblju sektorske su potpore bile prevladavajući cilj državne industrijske politike i činile su preko $76 \%$ svih potpora dok su horizontalne potpore činile samo I5\%.

Kao što se može i očekivati, u okviru sektorskih potpora rekorder je brodogradnja s I3 milijardi kuna uloženog javnog novca, zatim slijedi promet (Io milijardi kuna, od čega se najviše odnosi na HŽ), te radiotelevizijsko emitiranje s 5 milijardi kuna.

U okviru horizontalnih potpora najviše je sredstava uloženo u poticanje zapošljavanja (2,2 milijarde kuna). Slijede istraživanje i razvoj, te malo i srednje poduzetništvo s po milijardu kuna. Zaštita okoliša i ušteda energije nisu bile u posebnom fokusu javne politike i sa I87 milijuna kuna nalaze se gotovo na začelju horizontalnih potpora.

Promatra li se samo 20Io. - kao posljednja godina analiziranog razdoblja - vidljivo je da bitnih promjena nema. Naime, horizontalne potpore nisu doživjele pozitivan pomak te je njihov udio u ukupnim potporama čak manji za 3,2 strukturna boda (pad od I5 na II,8\%) u odnosu na cijelo promatrano razdoblje, što znači da politika potpora još uvijek nije doživjela važne strukturne promjene. To potvrđuje i kretanje sektorskih potpora čiji se udio u ukupnim potporama 20Io. još i povećao u odnosu na cijelo razdoblje za jedan strukturni bod sa 76,I na 77,I\%.

Usporedi li se pak struktura državnih potpora 20IO. s onom od EU27, postaje jasno koliki napor Hrvatska treba poduzeti da bi sprovela nužne strukturne promjene u gospodarstvu. Naime, dok u EU27 sektorske potpore 2010. čine $15 \%$, u Hrvatskoj iznose preko $68 \%{ }^{4}$ ukupnih potpora (bez prometa), dakle 4,5 puta više. Horizontalne potpore (zajedno s regionalnim) u EU27 predstavljaju čak 85\%, a u

4 Podaci u koloni 5 tablice I. pripremljeni su radi usporedbe udjela potpora u ukupnim potporama (bez prometa) kako se to čini u statistici EU-a. Prilikom izračuna udjela u ukupnim potporama (bez prometa) horizontalnim se potporama $u$ istoj statistici pridružuju i regionalne, što je učinjeno i u ovom tekstu (European Commission, 2OI2C).
Hrvatskoj su gotovo tri puta manje i čine oko 32\% ukupnih potpora bez prometa.

\section{DRŽAVNE POTPORE U UGOVORU O PRISTUPANJU HRVATSKE EUROPSKOJ UNIJI}

Iz navedenog slijedi da u Hrvatskoj na području državnih potpora u promatranom devetogodišnjem razdoblju nije bilo značajnih pomaka, što je samo pokazatelj da nisu učinjene značajnije strukturne reforme gospodarstva. Udio državnih potpora u BDP-u 2OIo. jedan je od najviših u Europi, a struktura potpora gotovo je zamrznuta u cijelom razdoblju s dominacijom sektorskih potpora, prvenstveno u brodogradnji i prometu.

Pristupanje EU-u trebalo bi donijeti velike promjene: obujam potpora morao bi konačno početi opadati, struktura bi im se trebala mijenjati na štetu sektorskih, a u korist horizontalnih potpora, a kontrolu nad državnim potporama preuzela bi EK.

Ugovorom o pristupanju utvrđuje se da je Hrvatska preuzela pravnu stečevinu EU-a, te se navode određeni uvjeti za njezino članstvo. U okviru odredbi Ugovora o pristupanju koje se odnose na tržišno natjecanje nalaze se i uvjeti o državnim potporama, a odnose se na obveze koje je Hrvatska preuzela u vezi restrukturiranja brodogradnje i čelika, te definiranja postojećih potpora. U nastavku su ukratko prikazane preuzete obveze na ova tri područja. ${ }^{5}$

\section{BRODOGRADNJA}

Ugovorom o pristupanju, Hrvatska se obvezala privatizacijom restrukturirati sljedeća brodogradilišta: 3. Maj, Brodotrogir, Brodosplit, Brodogradilište specijalnih objekata - Split i Brodogradilište Kraljevica. Zainteresirani su kupci dostavili planove restrukturiranja koje su prihvatili AZTN i EK, i oni će biti sastavni dio ugovora o privatizaciji zaključenog između Hrvatske i kupaca ovih poduzeća.

Predviđeni su i uvjeti koji se moraju poštovati u postupku restrukturiranja:

- Doprinos planu restrukturiranja iz vlastitih sredstava mora činiti barem 40\% ukupnog troška restrukturiranja. Sve potpore koje su brodogradilišta dobila nakon I. ožujka 2006. smatraju se potporama za restrukturiranje.

- Ukupan proizvodni kapacitet brodogradilišta mora se smanjiti u odnosu na razinu koja je postojala I. lipnja 2011. od 47I.324 BRT na 372.346 BRT, tj. za 2I\%, i to najkasnije u roku od godine dana od potpisivanja privatizacijskog ugovora. Smanjenje kapaciteta provest će se trajnim zatvaranjem navoza, prenamjenom navoza za vojnu proizvodnju

5 U kurzivu su navedene odredbe iz Ugovora o pristupanju. 
u skladu s Ugovorom o Europskoj uniji i/ili smanjivanjem površine proizvodnje.

- Ukupna godišnja proizvodnja svih brodogradilišta mora se u razdoblju od Io godina ograničiti na 323.6oo BRT, počevši od I. siječnja 20II. U okviru tog iznosa točno su navedeni limiti za suako brodogradilište.

Brodogradilišta neće primati nikakve nove potpore za sanaciju i restrukturiranje prije isteka roka od najmanje Io godina od dana potpisivanja ugovora o privatizaciji. Ugovori o privatizaciji biti će potpisani i poslani EK na odobrenje prije no što li Hrvatska pristupi EU-u I. srpnja 2013.

U slučaju da se ne ispune navedene obveze, nakon pristupanja EK može Hrvatskoj naložiti da osigura povrat svih potpora za sanaciju i restrukturiranje sa složenim kamatama, koje su određenom brodogradilištu dane od I. ožujka 2006.

EKće nadgledati provođenje planova restrukturiranja i poštivanje uvjeta iz Ugovora o pristupanju, osobito u vezi s iznosom državnih potpora, vlastitim doprinosom, smanjenjem kapaciteta, ograničenjem proizvodnje i mjerama oživljavanja brodogradilišta. Hrvatska će morati slati izvješća EK koja će nadgledati restrukturiranje brodogradilišta do kraja 2020. ${ }^{6}$

Navedeni uvjeti za restrukturiranje brodogradnje nisu specifični samo za Hrvatsku, već su predviđeni Pravilima o državnim potporama za sanaciju i restrukturiranje $\mathrm{e}^{7} \mathrm{koja}$ su sastavni dio pravne stečevine EU-a i vrijede za sve poduzetnike na području EU-a. Pravilima su općenito predviđene kompenzacijske mjere za smanjenje kapaciteta i proizvodnje, te vlastiti doprinos poduzetnika koji se restrukturira, a u Ugovoru o pristupanju samo su detaljnije razrađena za Hrvatsku.

Smisao kompenzacijskih mjera je da potpora stvara što manje negativnih učinaka na trgovinske uvjete. Ukoliko je neko poduzeće dobilo potporu, njegova se zastupljenost na tržištu mora ograničiti, jer bi u suprotnom bilo u puno povoljnijem tržišnom položaju od poduzeća koje nije dobilo potporu. Došlo bi do prekomjernog narušavanja tržišne utakmice, a takvu se potporu drži "suprotnom zajedničkom interesu”, dakle neusklađenom zajedničkom tržištu. Smanjenje kapaciteta i proizvodnje koje je Hrvatska dogovorila za svoja brodogradilišta, kompenzacijske su mjere za ulazak na zajedničko europsko tržište, tako da s obzirom na ogromne iznose državnih potpora dobivenih u prethodnom razdoblju, Hrvatska ne bi ostvarivala povoljniji položaj u odnosu na druga europska brodogradilišta.

6 Sažetak Dodatka VIII Ugovora o pristupanju.

7 Hrvatska je ova Pravila preuzela i objavila u NN 20/O7.
Doprinos planu restrukturiranja vlastitim sredstvima poduzetnika također je dio pravne stečevine i predviđen je Pravilima o državnim potporama za sanaciju i restrukturiranje u rasponu od $25 \%$ - mali, $40 \%$ - srednji i $50 \%$ - veliki poduzetnici. Smisao vlastitog doprinosa poduzetnika procesu restrukturiranja je da se iznos i intenzitet državne potpore te korištenje javnog novca strogo ograniči na najmanju neophodnu mjeru, te da se pojača odgovornost poduzetnika za provedbu restrukturiranja. Ugovorom o pristupanju predviđeno je sudjelovanje vlastitih sredstava u iznosu od 40\% ukupnog troška restrukturiranja hrvatskih brodogradilišta, čime su brodogradilišta svrstana u rang srednjih poduzetnika.

Važno je ponovo naglasiti da će EK nakon pristupanja EU-u, ukoliko se ne ispune obveze navedene Ugovorom o pristupanju, tj. da se četiri brodogradilišta ne privatiziraju uz dogovorene uvjete, naložiti Hrvatskoj povrat svih potpora za sanaciju i restrukturiranje (sa složenim kamatama), dobivenih nakon I. ožujka 2006. Prema službenim podacima AZTN-a, u razdoblju od 2006-Io. brodogradilišta su dobila Io,2 milijarde kuna državnih potpora ${ }^{8}$. Dodaju li se tome potpore dodijeljene 20II. i 20I2., a koje AZTN još mora izračunati i javno objaviti, kao i složene kamate, jasno je da je riječ o ogromnim iznosima koje bi brodogradilišta morala vratiti. To pokazuje s kolikim je izazovom suočena hrvatska Vlada, te koliko je važno nakon stečaja Brodogradilišta Kraljevica i potpisivanja ugovora o privatizaciji s DIV-om za Brodosplit - ubrzati i što prije riješiti privatizaciju 3. Maja i Brodotrogira9.

Zanimljivo je podsjetiti što su Malta i Poljska - dvije nove države članice sa značajnijom brodograđevnom industrijom - dogovorile u svojim ugovorima o pristupanju EU-u. Na Malti je brodogradnja s dva brodogradilišta najveća pojedinačna industrijska grana; obilježavala ju je prekapacitiranost, nedovoljna financijska sredstva, visoki troškovi rada i nedovoljna produktivnost. Kako bi se restrukturirala brodogradilišta koja su u državnom vlasništvu i proizvode gubitke, Malta je dogovorila prijelazne odredbe koje su bile pod nadzorom EK: dopuštene su joj potpore za restrukturiranje do ukupnog maksimalnog iznosa od 984 milijuna eura, u trajanju od 2002. do kraja 2008. Za razliku od Malte, Poljska, koja je imala veliki brodograđevni sektor, nije za njega dogovorila prijelazna razdoblja za primjenu državnih potpora, već su brodogradilišta Gdynia i Szczecin trebala do 2006. i 2004. okončati financijsko i materijalno restrukturiranje (European Commission, 2004.)

8 Izvor: Godišnja izvješća AZTN-a.

9 Vlada je 20. lipnja 20I2. prihvatila model privatizacije brodogradilišta 3. Maj za koje bi ponudu o kupnji dostavilo brodogradilište Uljanik nakon provedene privatizacije(kroz radničko dioničarstvo i dokapitalizaciju). Vlada je također Io. srpnja 20I2. prihvatila ponudu tvrtke Kemas energija za preuzimanje Brodotrogira. (http://www.vlada.hr/ $\mathrm{hr} /$ naslovnica) 
Važno je napomenuti da će se u Hrvatskoj nakon provedenog restrukturiranja i privatizacije, potpore brodogradnji i dalje moći dodjeljivati, i to u skladu s europskim Pravilima o državnim potporama brodogradnji (vidi okvir). Prema njima su potpore brodogradnji moguće u obliku regionalnih potpora, za inovacije, te za kreditiranje izvoza. No, općenito, brodogradnja će se moći pomagati kao i svi ostali poduzetnici, tj. u skladu s pravilima koja reguliraju ostale potpore za horizontalne namjene.

\section{Nova Pravila Europske unije za državne potpore brodogradnji}

Europska komisija usvojila je nova Pravila o državnim potporama brodogradnji (Framework on state aid to shipbuilding, (OJ 20II/C 364/o6)) koja su stupila na snagu i. siječnja 20I2., a vrijede do 3I. prosinca 20I3. Hrvatska još nije prenijela ova Pravila u svoje zakonodavstvo, no kako se radi o dijelu pravne stečevine EU-a, morat će ih primjenjivati. Pravila i dalje dopuštaju potporu za inovacije u brodogradilištima, za kreditiranje izvoza i regionalnu potporu. No više ne sadrže potpore za zatvaranje, zapošljavanje te za razvoj, što je bio sastavni dio "starih" Pravila o državnim potporama brodogradnji, jer EK smatra da te potpore nisu specifične samo za brodogradilišta, nego su dio ostalih pravila o potporama. EK predviđa da će nakon 20I3. potpore za inovacije i regionalnepotpore brodogradilištima takođerbitiuključene u ostala pravila o horizontalnim potporama.

\section{ǦELIK}

Ugovorom o pristupanju dogovoreno je da CMS Sisak d.o.o. vrati potpore za restrukturiranje koje je Željezara primila $u$ razdoblju od I. ožujka 2002. do 28. veljače 2007. u iznosu od I9 milijuna kuna, uvećanih za složene kamate. Ukoliko CMS Sisak ne isplati taj iznos, EK će, nakon pristupanja Hrvatske EU-u, naložiti Hrvatskoj da osigura povrat svih potpora za sanaciju i restrukturiranje koje je Željezara dobila nakon I. ožujka 2006. (uključujući i složene kamate). ${ }^{\text {Io }}$

Nakon 2007. privatizirane su dvije željezare u Hrvatskoj - Željezara Split d.d. postala je vlasništvo Zlomrexa iz Poljske, a Valjaonica cijevi Sisak d.o.o. ušla je u vlasništvo Commercial Metals International AG, Baar, Švicarska. Krajem 2008. smanjuje se proizvodnja u obje željezare, a na što je najvećim dijelom utjecalo stanje na svjetskom tržištu, te su obje željezare obustavile proizvodnju - Željezara Split u travnju 2009. (Vlada RH, 2OIO), a CMS Sisak u listopadu 2OII (European Commission, 20I2a).

Ugovorom o pristupanju dogovoren je povrat državnih potpora za CMS Sisak u iznosu od I9 milijuna kuna dobivenih u razdoblju od I. ožujka 2002. do 28. veljače 2007. CMS Sisak je priznao taj dug koji do kraja veljače 20I2. još nije bio uplaćen (European Commission, 20I2a). CMS Si- sak je u lipnju 20ı2. prodala Željezaru tvrtki Danieli iz Italije, te se očekuje reguliranje naplate duga. ${ }^{\text {II }}$ Ako do pristupanja CMS Sisak ne uplati ukupan dug, EK će naložiti da Hrvatskoj osigura povrat svih potpora za sanaciju i restrukturiranje koje je taj poduzetnik dobio do I. ožujka 2006., sa složenim kamatama. Potpore će morati vratiti i Željezara Split; u svibnju 2OII. AZTN je za Željezaru Split naložila povrat potpora s pripadajućim kamatama u iznosu od 289 milijuna kuna, jer zbog stečaja nisu ispunjeni uvjeti vezani uz investiranje, ostvarenje dobiti, i sl., čime su nastupile nepravilnosti u provedbi propisa o potporama..$^{12}$

Prema podacima AZTN-a (2OII), osim 2,2 milijuna kuna $u$ 2009. za minimalne plaće radnicima koje je isplatio Hrvatski fond za privatizaciju, nakon odlaska poljskog investitora iz Željezare Split, tijekom 2008. i 20IO. nisu dodjeljivane nove potpore industriji željeza i čelika.

Na području EUı2 industrija čelika posebno je značajna u Poljskoj i Češkoj, pa su za te zemlje u Ugovorima o pristupanju dogovorena prijelazna razdoblja. Za nešto više od dvije godine od pristupanja (do 3I. prosinca 2006.) morale su okončati proces restrukturiranja industrije čelika. EK im je - uz određene strogo nadzirane uvjete - dopustila dodjelu državnih potpora za razdoblje 1997-2003.: Češkoj 4I3, a Poljskoj 769 milijuna eura (European Commission, 2004).

Iako je sudbina industrije željeza i čelika u Hrvatskoj neizvjesna, budući investitori mogu računati na državne potpore sukladno Pravilima o državnoj potpori u sektoru čelika (NN I34/o8) koja se temelje na Zakonu o državnim potporama, odnosno pravnoj stečevini EU-a.

\section{POSTOJEĆE POTPORE}

Ugovorom o pristupanju predviđeno je da se određene državne potpore koje su u Hrvatskoj stupile na snagu prije dana pristupanja i koje se primjenjuju i nakon toga, smatraju od pristupanja "postojećim potporama", i to:

- potpore odobrene prije I. ožujka 2002.;

- potpore posebno navedene u Popisu uz Dodatak IV Ugovora o pristupanju (zakoni o slobodnim zonama, HRT-u, znanstvenoj djelatnosti i visokom obrazovanju; zračne luke Osijek i Rijeka; Rockwool i Program financiranja nakladništva);

- potpore za koje AZTN prije datuma pristupanja utvrdi da su kompatibilne s pravnom stečevinom i na koje Komisija nema primjedbi.

II http://www.tportal.hr/biznis/gospodarstvo/I97696/Talijanikupili-zeljezaru-Sisak.html

I2 Rješenje Agencije za zaštitu tržišnog natjecanja, NN 58/II. 
Sve potpore koje će se nastaviti dodjeljivati nakon pristupanja, a koje ne spadaju u navedene tri kategorije, smatrat će se novim potporama. ${ }^{13}$

Važno je razlikovati postojeće i nove potpore. One za koje je Ugovorom o pristupanju dogovoreno da se smatraju “postojećim”, EK ima pravo preispitati i nakon pristupanja EU-u. Ukoliko se pokaže da nisu u skladu s pravnom stečevinom, EK može narediti izmjenu ili ukidanje, ali ne može naložiti povrat odobrenih potpora. Za razliku od toga, sve ostale potpore koje se smatraju "novim", EK isto tako može preispitati, ali može zatražiti i vraćanje već odobrenih iznosa potpora. U Popisu uz Dodatak IV Ugovora o pristupanju navedeno je sedam mjera državnih potpora koje se nastavljaju primjenjivati nakon ulaska Hrvatske u EU, a za koje je dogovoreno da se smatraju “postojećim potporama”. Hrvatska je zatražila da još četiri mjere usklađene s pravnom stečevinom EU-a uđu na taj popis te da se i one nakon pristupanja smatraju "postojećim potporama” (European Commission, 20I2a). Naime, budućoj državi članici u interesu je da se što više državnih potpora smatra "postojećim", jer u slučaju da EK ocijeni da se radi o potporama koje nisu u skladu s pravnom stečevinom, može doći do njihove izmjene ili ukidanja, ali ne i do povrata već dodijeljenih potpora. Ilustracije radi, $u$ procesu pristupanja novih članica EUıo EK je najviše postojećih državnih potpora odobrila Češkoj - I2O, a najmanje Estoniji - samo 3. Ove mjere postale su sastavnim dijelom Ugovora o pristupanju (European Commission, 2004).

Na području državnih potpora EU za nove države članice nameće snažnu vanjsku uvjetovanost (external conditionality), jer se to područje smatra ključnim za sprečavanje narušavanja tržišnog natjecanja i očuvanje zajedničkog tržišta (Mulas-Granados, Koranchelian i Segura-Ubiergo, 2008.). Vanjska uvjetovanost stvara u državama koje pristupaju EU-u odlučujući pritisak da promijene svoje državne potpore. To je vidljivo iz kretanja i strukture državnih potpora u EUı2, gdje je u gotovo svim državama došlo do pada udjela potpora u BDP-u i do porasta izdvajanja $\mathrm{u}$ horizontalne ciljeve. ${ }^{14}$ Vanjska uvjetovanost, odnosno pritisak EU-a, potaknula je i promjene državnih potpora u Hrvatskoj, koje su se niz godina odgađale: restrukturiranje i privatizacija industrije čelika, brodogradnje i željeznica dinamizirale su se približavanjem datuma ulaska u EU, do kada bi ovi procesi trebali biti okončani.

I4 Vidjeti više u Jović (2OI2)

\section{POTPORE U HRVATSKOJ NAKON PRISTUPANJA EUROPSKOJ UNIJI}

U izgradnji sustava državnih potpora Hrvatska je u predpristupnom razdoblju prošla sličan put kao i ostale članice koje su EU-u pristupile 2004. i 2007. Tijekom predpristupnog razdoblja trebale su u svoje zakonodavstvo uključiti sustav kontrole državnih potpora sličan onom koji postoji u EU-u, da bi se uspostavilo odobravanje, kontrola, ali i povrat nelegalnih potpora, trebalo je osnovati nacionalno tijelo zaduženo za provođenje tog sustava. Hrvatska je udovoljila ovim zahtjevima donijevši odgovarajuće zakonske propise, osnovala je Agenciju za tržišno natjecanje i u svoje zakonodavstvo prenijela pravila o državnim potporama koje su sastavni dio pravne stečevine EU-a. Ova pravila primjenjuje već niz godina, ti. sve od potpisivanja Sporazuma o stabilizaciji i pridruživanju 200I., od kada AZTN postepeno, uporno i sve dosljednije uključuje ova pravila u gospodarski život poduzetnika primatelja potpora i javne vlasti - davatelja potpora.

Nakon pristupanja u EU, kontrola zakonitosti državnih potpora, njihov nadzor i povrat prelaze $u$ isključivu nadležnost EK koja je jedina odgovorna za odlučivanje o državnim potporama svih država članica. Time se mijenja i uloga AZTN-a koja će, kao što to sada čine nacionalna tijela svih država članica, postati pomoćno tijelo EK za evidentiranja i notifikacije potpora, prikupljanje podataka, vođenje registra potpora, informiranje, pomoć davateljima potpora i sl. Prijelaz nadležnosti za državne potpore u ruke EK ne znači da Hrvatska više neće moći dodjeljivati potpore. Dodjeljivat će ih kako to čine sve druge države članice. Financijsko podupiranje poduzetnika u EU-u nije zabranjeno; odvija se po istim pravilima koja AZTN već sada primjenjuje, samo što će ih nakon I. srpnja 20I3. primjenjivati EK. U tom će smislu Hrvatska trebati učiniti odrađene administrativne, tehničke i kadrovske prilagodbe, kako bi AZTN EK mogao uspješno opsluživati.

No EK priprema krupne promjene u sustavu državnih potpora koje bi na snagu trebale stupiti do kraja 20I3. te bi praktički dočekale Hrvatsku odmah nakon pristupanja. Cilj im je modernizacija državnih potpora, a dio su šireg konteksta usmjeravanja ukupne energije Unije na poticanje gospodarskog rasta, usmjeravanja državnih potpora na uklanjanje tržišnih neuspjeha i što racionalnije korištenje javnih sredstava. EK će preispitati, pojednostavniti i izmijeniti veliki dio pravila za dodjelu potpora, posebno onih za sanaciju i restrukturiranje, zaštitu okoliša i regionalnih potpora, te ce ubrzati procese donošenja odluka. AZTN mora sve ove promjene pozorno pratiti i administrativno se pripremiti za sudjelovanje u njihovoj primjeni (European Commission, 20I2b). 
Nakon pristupanja EU-u, veličina i struktura državnih potpora sve će više sličiti onoj koje imaju sadašnje države članice. Može se očekivati trend smanjivanja udjela potpora u BDP-u, kretanje prema "manjim, ali boljim" potporama i smanjivanje sektorskih potpora. To znači usmjeravanje državnih potpora na financiranje tzv. horizontalnih ciljeva za istraživanje i razvoj, zaštitu okoliša, zapošljavanje, regionalni razvitak, i sl. Smanjivanje se prvenstveno odnosi na sektorske potpore poduzećima u teškoćama koje iskrivljuju tržišta i daju prednost jednom, obično manje efikasnom poduzeću kojemu potpore samo odgađaju neminovan odlazak s tržišta.

Što se više približava datum ulaska u EU, vanjska uvjetovanost djeluje sve jače, pa se i promjene na području državnih potpora odvijaju sve dinamičnije: restrukturiranje i privatizacija brodogradnje, kao najvećeg primatelja potpora morat će se okončati do pristupanja EU-u (ili će brodogradilišta morati vratiti potpore dobivene nakon I. ožujka 2006.); stečajem u željezarama Split i Sisak potpore tom sektoru su nakon 2008. posve izostale, a naložen je i povrat nelegalnih potpora za obje željezare; restrukturiranje Hrvatskih željeznica - najvećeg primatelja državnih potpora u prometnom sektoru - je u pripremi i trebalo bi se odvijati tijekom ove godine jer ulaskom u EU slijedi liberalizacija željezničkog tržišta i dolazak drugih operatera ${ }^{15}$; u državnom proračunu Ministarstvo financija ne planira rast subvencija, ${ }^{16}$ već će ih u 20I4. zadržati na istoj nominalnoj razini kao i 20I3. (Ministarstvo financija RH, 20I2). Ipak značajni pomaci prema horizontalnim potporama još se ne naziru jer AZTN-u tijekom 20II. nisu dostavljeni na odobrenje programi kojima bi se u značajnijoj mjeri povećale potpore horizontalnim ciljevima (AZTN, 2OII).

Pristupanje EU-u donosi promjene državnih potpora $u$ Hrvatskoj, pa više neće biti moguće održavanje "starog" modela u kojem se "selektivno podupiru sektori u teškoćama, na štetu onih koji generiraju proizvodnju roba i usluga visoke dodane vrijednosti ili razvoj novih oblika poduzetništva” (AZTN, 2OII). Bilo bi bolje da to što prije prihvate svi gospodarski akteri: od državnih institucija, sindikata, menadžera, pa do zaposlenih, ali i svih građana. Došlo je vrijeme kad se sve oskudnija državna sredstva napokon moraju početi racionalno koristiti.

\section{LITERATURA:}

AZTN, 20II. Godišnje izvješće o državnim potporama za 20Io. godinu. Zagreb: Agencija za zaštitu tržišnog natjecanja. Dostupno na: [http://www.aztn.hr/uploads/

I5 Prema izjavi ministra Hajdaš Dončića od Io. srpnja 2012 (Žabec, 2OI2).

I6 Subvencije su najvažniji oblik dodjele potpora, tj. 20Io. su činile 72,6\% ukupno dodijeljenih potpora (AZTN, 2OII).
documents/tn/godisnja_izvjesca/Godisnje_izvjesce_ o_drzavnim_potporama_2oio.pdf].

European Commission, 2004. State Aid Scoreboard autumn 2004 update. Brussels, I6. II. 2004. COM (2004)750 final. Dostupno na: [http://ec.europa.eu/ competition/state_aid/studies_reports/archive/2004_autumn_en.pdf].

European Commission, 2012a. Monitoring report on Croatia's accession preparations. Brussels, April 24, 2012. Dostupno na: [http://ec.europa.eu/commission_2OIO-OI4/fule/docs/news/2OI2O424_report_ final.pdf].

European Commission, 2012b. State Aid Modernisation. Dostupno na: [http://ec.europa.eu/competition/state_aid/modernisation/index_en.html].

European Commission, 2012c. Scoreboard - Data on state aid expenditure. Dostupno na: [http://ec.europa. eu/competition/state_aid/studies_reports/expenditure.html].

Jović, I., 2012. "EUı2: državne potpore prije i poslije pristupanja Europskoj uniji”. Newsletter, br. 69. Dostupno na: [http://www.ijf.hr/upload/files/file/newsletter/ 69.pdf].

Kesner-Škreb, M., 2012. "Osam nalaza o državnim potporama u Hrvatskoj 2012.. Aktualni osvrti, br. 37. Dostupno na: [http://www.ijf.hr/upload/files/file/osvrti/37.pdf].

Ministarstvo financija RH, 20I2. Državni proračun Republike Hrvatske za 2012. godinu i projekcije za 2013. 20I4. Dostpuno na: [http://www.mfin.hr/hr/drzavniproracun-2OI2-godina].

Mulas-Granados, G., Koranchelian, T. i Segura-Ubiergo, A., 2008. "Reforming Government Subsidies in the New Member States of the European Union”. IMF Working Paper, WP/o8/165. Washington: International Monetary Fund.

Vlada RH, 20Io. Pregovaračka stajališta Republike Hrvatske za međuvladinu konferenciju o pristupanju Republike Hrvatske Europskoj uniji za poglavlje 8. "Tržišno natjecanje". Zagreb, I. travnja 20Io. Dostupno na: [http:// www.mvep.hr/custompages/static/hrv/files/pregovori/4/o8.pdf].

Rješenje Agencije za zaštitu tržišnog natjecanja, NN 58/II. Zagreb: Narodne novine.

Žabec, K., 20I2. "HŽ kreće u restrukturiranje: Do kraja godine 2700 radnika ostat će bez posla!” Jutarnji list, Io. srpnja 20I2. Dostupno na: [http://www.jutarnji.hr/ restrukturiranje-u-hz-holdingu--do-kraja-godine270o-radnika-ostat-ce-bez-posla/IO40I6o/]. 